\title{
Using aerial photogrammetry to detect changes in body condition of endangered southern resident killer whales
}

\author{
Holly Fearnbach $^{1,3, *}$, John W. Durban' ${ }^{2}$, David K. Ellifrit ${ }^{1}$, Kenneth C. Balcomb ${ }^{1}$ \\ ${ }^{1}$ Center for Whale Research, 355 Smuggler's Cove Road, Friday Harbor, WA 98250, USA \\ ${ }^{2}$ Marine Mammal and Turtle Division, Southwest Fisheries Science Center, National Marine Fisheries Service, NOAA, \\ 8901 La Jolla Shores Dr., La Jolla, CA 92307, USA \\ ${ }^{3}$ Present address: $\mathrm{SR}^{3}$, SeaLife Response, Rehabilitation and Research, PO Box 1404, Mukilteo, WA 98275, USA
}

\begin{abstract}
The endangered population of southern resident killer whales Orcinus orca is hypothesized to be food-limited, but uncertainty remains over if and when the availability of their primary prey, Chinook salmon Oncorhynchus tshawytscha, is low enough to cause nutritional stress. To measure changes in body condition, we collected 1635 measurable images from a helicopter hovering 230-460 $\mathrm{m}$ above whales, and linked these to individuals with distinctive natural markings. Head width (HW), measured at $15 \%$ of the distance between the blowhole and the dorsal fin (BHDF), was measured from images of 59 individuals in 2008 (from a population of 84) and 66/81 individuals in 2013, enabling assessment of between-year changes for 44 individuals (26 females, 18 males). Of these, 11 had significant declines in the ratio of HW/BHDF compared to 5 with significant increases. Two whales with declines died shortly after being photographed, suggesting a link between body condition and mortality. Most (8/11) of the significant declines in condition were from 1 social pod (J-pod), and all the whales that increased in condition were from one of the other 2 pods, K-pod $(n=3)$ and L-pod $(n=2)$. Notably, 11/16 whales that changed condition were reproductive-aged females and there were no adult males with significant changes. This likely reflects the increased energetic costs of lactation to reproductive females, and the nutritional help provided to adult males through prey sharing. These data demonstrate the utility of aerial photogrammetry as a non-invasive approach for providing quantitative data on body condition, and support monitoring the condition of reproductive females as key indicators of nutritional stress.
\end{abstract}

KEY WORDS: Orca $\cdot$ Photogrammetry $\cdot$ Nutritional stress $\cdot$ Salmon $\cdot$ Body condition

\section{INTRODUCTION}

The southern resident population of killer whales (SRKWs, Orcinus orca) aggregates annually off southern Vancouver Island to feed on returning runs of salmon, particularly Chinook (Oncorhynchus tshawytscha; Ford \& Ellis 2006, Hanson et al. 2010). SRKWs were listed as endangered under the Endangered Species Act in the US in 2005 (National Marine

*Corresponding author: hfearnbach@sealifer3.org
Fisheries Service 2008) and the Species at Risk Act in Canada in 2002 (Fisheries and Oceans Canada 2008). This population is hypothesized to be food-limited, and declines in the availability of Chinook salmon have been correlated with increased mortality, decreased fecundity, changes in social cohesion and declines in adult size in SRKWs (Parsons et al. 2009, Ward et al. 2009, Ford et al. 2010, Fearnbach et al. 2011, Foster et al. 2012a). However, the report of an

() The authors H.F., D.K.E., and K.C.B., and outside the USA, the US Government 2018. Open Access under Creative Commons by Attribution Licence. Use, distribution and reproduction are unrestricted. Authors and original publication must be credited. Publisher: Inter-Research · www.int-res.com 
independent science panel on the effects of salmon fisheries on SRKWs highlighted uncertainty over the link between prey availability and population dynamics (Hilborn et al. 2012). Specifically, the panel cited a key data gap of whether the abundance of the species' preferred Chinook salmon prey is low enough to cause nutritional stress and recommended the use of photogrammetry to assess the nutritive status of the SRKW population.

The utility of aerial photogrammetry as a non-invasive approach for providing quantitative data on body condition has previously been demonstrated for large whales (e.g. Perryman \& Lynn 2002, Miller et al. 2012). Similarly, aerial photogrammetry has been successfully used to estimate length and patterns of growth of SRKWs (Fearnbach et al. 2011), but here we extended these approaches to measure finer-scale changes in the condition of individual whales that were tracked over time to infer nutritional health.

\section{MATERIALS AND METHODS}

We used a Robinson R44 Clipper helicopter, launched from Friday Harbor Airport, Washington State, USA, to conduct photogrammetry flights in each of September 2008 and 2013. Whales were primarily photographed in US waters, to the west and south of San Juan Island, Washington State, but 1 encounter occurred in Canada off the southeast end of Vancouver Island, British Columbia. Photographic survey methods have been previously described (Fearnbach et al. 2011). In 2008, we obtained vertical photographs of resolution $4288 \times 2848$ pixels (13.1 effective megapixels) using a Nikon D300 digital SLR camera equipped with a fixed focal length $180 \mathrm{~mm}$ f2.8 AF Nikkor lens. The lens was used either with or without a $1.4 \times$ Kenko Pro extender, to achieve a realized focal length of either 378 or $270 \mathrm{~mm}$. In 2013, we upgraded to a Nikon D800E camera with a fixed focal length $300 \mathrm{~mm}$ f4 Nikkor lens to collect images with a resolution of $7360 \times 4912$ pixels (36.3 effective megapixels). Once killer whales were located either visually from the helicopter or in coordination with a boat-based team, the photographer (wearing a harness) leaned out of the open passenger door to shoot photographs vertically down on the target whale. A bubble-level was attached to the back of the hand-held camera to ensure it was orientated vertically, while the photographer used a motor-drive to capture as many images as possible of the surfacing whale. In order to avoid behavioral disturbance to the whales, flight operations over whales were conducted between $230 \mathrm{~m}$ (750 ft) and $460 \mathrm{~m}$ (1500 ft) above the whales, and approaches below $305 \mathrm{~m}$ (1000 ft) were conducted under National Marine Fisheries Service Permit \#155569 in the USA and Species-At-Risk Act Permit \#13-278 in Canada.

Individual identifications were assigned to all whales in usable aerial images by an analyst (D.K.E.) with $>20$ yr of experience of photo-identification of SRKWs and confirmed by a second experienced analyst (H.F.). Individual identifications were made by comparing the overhead images of saddle patch pigmentation and scarring (see Fearnbach et al. 2011; their Fig. 1) to the most current boat-based photoidentification catalog of saddle patches of SRKWs (Ford et al. 2000, K. C. Balcomb et al. unpubl. data), and also by reviewing boat-based identification images that were collected simultaneously by the boatbased team. Ages of whales were assigned to individuals based on the established method outlined in Fearnbach et al. (2011). Age estimates of whales born since the start of the photo-identification study in the early 1970s were based on long-term longitudinal birth and sighting records (Ford et al. 2000, K. C. Balcomb et al. unpubl. data). Age estimates of whales born prior to the start of the photo-identification study were based on the size development of dorsal fins for males and the age of oldest offspring for females, as described by Olesiuk et al. $(1990,2005)$ and presented in Ford et al. (2000). Following Olesiuk et al. (1990), ages were standardized by considering whales to be $0.5 \mathrm{yr}$ old in their first summer (May to September) census period. Summaries of data by age/sex classes refer to the age of the individual in 2013. Sex was determined by visual observation of genital anatomy and pigmentation (e.g. Ford et al. 2000), by the development of sexual secondary characteristics in males (particularly the dorsal fin), or by the birth of a calf in females (Ford et al. 2000, K. C. Balcomb et al. unpubl. data).

Only images where the whales were directly below the helicopter and in straight orientation (i.e. no tilt in the body axis, as indicated by eye-patch orientation; see Fig. 1) were selected for measurement and included in analysis. The photo-processing software ImageJ (http://rsb.info.nih.gov/ij/) was used to measure the distance (in pixels) between points along the body axis (see Fig. 2) including: the center of the blowhole to the anterior insertion of the dorsal fin (BHDF), and head width (HW, the width of the head at a distance of $15 \%$ of the total BHDF). This area behind the cranium has been shown to be a sensitive indicator of nutritional status in cetaceans, as they lose adipose tissue in this region when they are in poor condition, resulting in a 'peanut head' appear- 

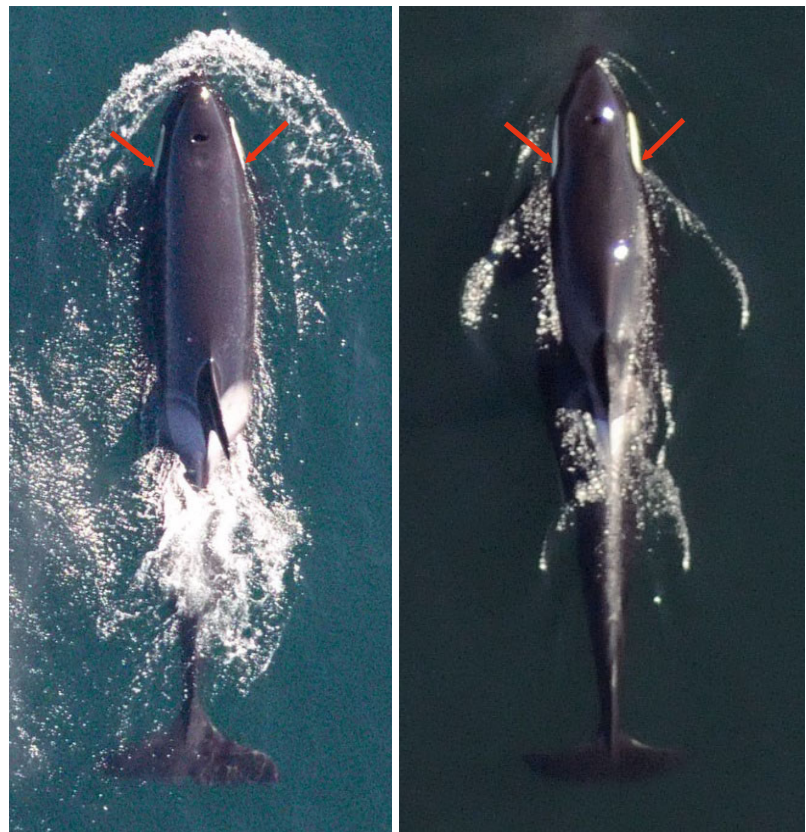

Fig. 1. K13, a robust 41.5 yr old female Orcinus orca (left) and L67, an emaciated $23.5 \mathrm{yr}$ old female that subsequently died (right). Arrows show where head width (HW) measurement was taken at $15 \%$ of the distance between the blowhole and anterior insertion of the dorsal fin (BHDF). Note that the white eye patches of K13 angle outward towards the posterior, while the eye patches of L67 angle inward and follow the shape of the skull ance (see our Fig. 1; Pettis et al. 2004, Bradford et al. 2012, Joblon et al. 2014). We used HW as a proportion of the BHDF as an index of nutritional status; both were measured in pixels and were required to be taken from the same image. For all metrics, we required a minimum of at least 3 estimates to include an individual in the subsequent data analyses.

\section{RESULTS}

In total, 18 flights (10 in 2008, 8 in 2013) were flown, with an average flight time of $75 \mathrm{~min}$ (min.-max. range: $30-118 \mathrm{~min}$ ). In total, 9777 aerial photographs were taken from an average altitude of $302 \mathrm{~m}$ (range: 230-407 m) in 2008, compared to $337 \mathrm{~m}$ (range: $230-460 \mathrm{~m}$ ) in 2013. Measurements of both HW and BHDF were possible from 1635 measurable-quality images that could be linked to 130 whale-by-year identifications (median per individual per year $=9$ images, $\min .=1$, max. $=89$ ). Limiting to only cases where an individual was imaged 3 or more times in a year provided a sample of 59 individuals (32 females and 27 males) in 2008 from a population of 84 animals alive at the time, and 66 individuals (38 females and 28 males) from a population of 81 in 2013. We were able to evaluate changes in individual condition for 44 whales (26 females and 18 males) represented in both samples. This included members of all 3 social pods ( $\mathrm{J}$-pod $=16$ whales, K-pod $=16, \mathrm{~L}-$ pod $=12$; Parsons et al. 2009).

The individual whales with the smallest HW/BHDF ratios were reproductive-aged females (10-42 $\mathrm{yr}_{\text {; }}$ Ward et al. 2016), and juveniles (<10 yr) had the largest HW/BHDF ratios (Fig. 2, Table 1). Of the 44 individuals with longitudinal measurements, 11 were measured to have significant decreases in HW/ BHDF ( $t$-test, $\mathrm{p} \leq 0.05$ ) between the 2 sampling years, and only 5 showed significant increases (Fig. 2, Table 1). Most $(8 / 11)$ of the significant declines in condition were from J-pod, while 2 were from K-pod and 1 was from L-pod. All the whales that increased in condition were from K-pod $(n=3)$ and L-pod $(n=$ 2 ); there were no J-pod whales that increased significantly in condition. Notably, $11 / 16$ whales that changed condition were reproductive-aged females; there were no adult males $(21+y r)$ and change or those just measured in 1 sampling period 
Table 1. Details of individual southern resident killer whales Orcinus orca sampled in aerial photographs in both 2008 and 2013. ID number includes pod designation (, $\mathrm{K}$ or L). The key photogrammetry measurement was the ratio of head width (HW, measured at $15 \%$ of the distance between the blowhole and anterior insertion of the dorsal fin [BHDF]) to BHDF, with standard deviation (SD) shown for repeat measurements within each year (a minimum of 3 measures required for inclusion). HW/BHDF was compared between sampling periods for each individual using $t$-tests, and significant results $(p \leq 0.05)$ are in bold. Values given as 0.00 are all $\leq 0.003$

\begin{tabular}{|c|c|c|c|c|c|}
\hline \multirow[t]{2}{*}{ ID } & \multirow[t]{2}{*}{ Sex } & \multirow[t]{2}{*}{ Birth year } & \multicolumn{2}{|c|}{ HW/BHDF (SD) } & \multirow[t]{2}{*}{$\mathrm{p}$} \\
\hline & & & 2008 & 2013 & \\
\hline J14 & $\mathrm{F}$ & 1974 & $0.44(0.02)$ & $0.44(0.02)$ & 0.85 \\
\hline J16 & $\mathrm{F}$ & $1972^{\mathrm{a}}$ & $0.44(0.01)$ & $0.43(0.02)$ & 0.39 \\
\hline J17 & $\mathrm{F}$ & 1977 & $0.46(0.01)$ & $0.44(0.02)$ & 0.00 \\
\hline J19 & $\mathrm{F}$ & 1979 & $0.45(0.02)$ & $0.46(0.03)$ & 0.12 \\
\hline $\mathrm{J} 22$ & $\mathrm{~F}$ & 1985 & $0.48(0.01)$ & $0.48(0.01)$ & 0.26 \\
\hline $\mathrm{J} 27$ & M & 1992 & $0.45(0.01)$ & $0.45(0.03)$ & 0.21 \\
\hline J28 & $\mathrm{F}$ & 1993 & $0.44(0.03)$ & $0.43(0.02)$ & 0.05 \\
\hline J31 & $\mathrm{F}$ & 1995 & $0.44(0.01)$ & $0.41(0.02)$ & 0.00 \\
\hline J34 & M & 1998 & $0.48(0.00)$ & $0.48(0.03)$ & 0.66 \\
\hline J35 & $\mathrm{F}$ & 1998 & $0.44(0.02)$ & $0.42(0.02)$ & 0.02 \\
\hline J36 & $\mathrm{F}$ & 1995 & $0.52(0.03)$ & $0.42(0.01)$ & 0.02 \\
\hline J38 & M & 2003 & $0.53(0.03)$ & $0.53(0.03)$ & 0.74 \\
\hline J39 & M & 2003 & $0.51(0.01)$ & $0.47(0.03)$ & 0.00 \\
\hline J40 & $\mathrm{F}$ & 2005 & $0.47(0.03)$ & $0.42(0.02)$ & 0.01 \\
\hline J42 & $\mathrm{F}$ & 2007 & $0.46(0.03)$ & $0.44(0.03)$ & 0.23 \\
\hline J8 & $\mathrm{F}$ & $1933^{a}$ & $0.46(0.02)$ & $0.41(0.02)$ & 0.01 \\
\hline K12 & $\mathrm{F}$ & $1972^{\mathrm{a}}$ & $0.44(0.01)$ & $0.47(0.02)$ & 0.01 \\
\hline K13 & $\mathrm{F}$ & $1972^{\mathrm{a}}$ & $0.43(0.01)$ & $0.45(0.03)$ & 0.03 \\
\hline K14 & $\mathrm{F}$ & 1977 & $0.47(0.02)$ & $0.47(0.02)$ & 0.77 \\
\hline K16 & $\mathrm{F}$ & 1985 & $0.44(0.02)$ & $0.47(0.03)$ & 0.02 \\
\hline K20 & $\mathrm{F}$ & 1986 & $0.43(0.02)$ & $0.42(0.02)$ & 0.16 \\
\hline K21 & M & 1986 & $0.46(0.02)$ & $0.47(0.01)$ & 0.40 \\
\hline K22 & $\mathrm{F}$ & 1987 & $0.43(0.02)$ & $0.42(0.02)$ & 0.44 \\
\hline K25 & M & 1991 & $0.46(0.01)$ & $0.45(0.01)$ & 0.25 \\
\hline K26 & M & 1993 & $0.47(0.02)$ & $0.47(0.01)$ & 0.78 \\
\hline K27 & $\mathrm{F}$ & 1994 & $0.45(0.01)$ & $0.43(0.01)$ & 0.02 \\
\hline K33 & M & 2001 & $0.45(0.01)$ & $0.44(0.00)$ & 0.06 \\
\hline K34 & M & 2002 & $0.45(0.03)$ & $0.44(0.00)$ & 0.75 \\
\hline K35 & M & 2003 & $0.47(0.04)$ & $0.48(0.03)$ & 0.60 \\
\hline K36 & $\mathrm{F}$ & 2003 & $0.45(0.02)$ & $0.44(0.02)$ & 0.13 \\
\hline K38 & M & 2005 & $0.46(0.01)$ & $0.45(0.03)$ & 0.34 \\
\hline K42 & M & 2008 & $0.51(0.01)$ & $0.47(0.04)$ & 0.02 \\
\hline L103 & $\mathrm{F}$ & 2003 & $0.41(0.01)$ & $0.42(0.02)$ & 0.43 \\
\hline L105 & M & 2005 & $0.46(0.02)$ & $0.45(0.02)$ & 0.32 \\
\hline L109 & M & 2007 & $0.44(0.00)$ & $0.45(0.03)$ & 0.03 \\
\hline L41 & M & 1977 & $0.45(0.02)$ & $0.43(0.00)$ & 0.06 \\
\hline L53 & $\mathrm{F}$ & 1977 & $0.45(0.01)$ & $0.41(0.01)$ & 0.00 \\
\hline L55 & $\mathrm{F}$ & 1977 & $0.39(0.01)$ & $0.42(0.02)$ & 0.00 \\
\hline L72 & $\mathrm{F}$ & 1986 & $0.44(0.01)$ & $0.43(0.00)$ & 0.60 \\
\hline L82 & $\mathrm{F}$ & 1990 & $0.42(0.01)$ & $0.41(0.02)$ & 0.12 \\
\hline L86 & $\mathrm{F}$ & 1991 & $0.43(0.01)$ & $0.44(0.03)$ & 0.41 \\
\hline L87 & M & 1992 & $0.46(0.01)$ & $0.46(0.02)$ & 0.76 \\
\hline L92 & M & 1995 & $0.43(0.01)$ & $0.44(0.01)$ & 0.17 \\
\hline L95 & M & 1996 & $0.47(0.02)$ & $0.46(0.02)$ & 0.49 \\
\hline
\end{tabular}

${ }^{a}$ Birth year is an estimate for individuals born prior to the commencement of annual monitoring (Ford et al. 2000) only 1 sub-adult male (10-21 yr) with significant changes. Two of the whales with significant declines in condition died prior to the following summer census, including 1 reproductive-age female and 1 postreproductive female. One additional female was documented with a pronounced 'peanut head' depression behind her cranium in 2008 (see L67 in Fig. 1) and died shortly after being photographed.

\section{DISCUSSION}

Key indicators of nutritional stress in mammalian populations include reduced body size, survival and reproduction (see Trites \& Donnelly 2003), all which have been documented in SRKWs (Ward et al. 2009, Ford et al. 2010, Fearnbach et al. 2011). We developed aerial photogrammetry to monitor the body condition of SRKWs to reduce uncertainty about nutritional status and inform management actions aimed at maintaining an adequate food supply. A key feature of our approach was to link photogrammetry measurements to individual whales of known age and life histories; we were able to monitor changes in body condition for 43 identifiable individuals that were imaged 5 yr apart, in 2008 and 2013 (time span due to funding constraints, not design).

Twenty-five percent (11/44) of these whales showed significant declines in body condition compared to only $11 \%$ (5/44) with significant increases, but these declines were not distributed evenly throughout the population. Most (8/11) were from 1 social pod (Jpod), which spends the greatest time in the inshore waters around southern Vancouver Island during summer (Hauser et al. 2007), where the whales feed primarily on Chinook salmon bound for the Fraser River (Hanson et al. 2010, Ford et al. 2016). These observed declines in body condition are consistent with a declining trend in an abundance index of Chinook salmon returning to the Fraser River over the same time period (Albion Test Fishery Chinook salmon catch per unit effort [CPUE], www.pac.dfompo.gc.ca/fm-gp/fraser/docs/commercial/albionchinook-quinnat-eng.html), supporting the hypothesis that changes in body condition relate to nutritional stress. The population abundance of SRKWs also declined over the same time period from 84 individuals in September 2008 to 81 individuals in September 2013 (K. C. Balcomb et al. unpubl. data), and 2 of the 11 whales measured with declining body condition died shortly after being photographed, suggesting a link between body condition and mortality. Notably, however, the larger number of whales detected with 
significant declines in condition illustrates the sensitivity of the photogrammetry approach for filling key data gaps on whale health, before condition becomes terminal. Similarly, the apparent difference in condition between the pods suggests that future monitoring of condition relative to more detailed data on pod-specific ranging patterns and prey preferences, if available, may help to focus recovery actions by identifying geographical areas and times when whales are nutritionally constrained and key salmon runs that it may be important to manage.

Notably, 11/16 whales that changed condition were reproductive-aged females and there were no adult males with significant changes. This likely reflects the increased energetic costs to adult females of lactation (see Noren 2011), and the release from these costs when lactation ceases. However, there is likely prolonged dependency on females through assistance with foraging (Foster et al. 2012b) and prey sharing with adult offspring and kin, notably males (Ford \& Ellis 2006, Wright et al. 2016). This prey sharing may buffer some age classes, particularly males, to the effects of food limitation, and conversely put extra nutritional stress on females as they continue to provision their offspring and kin into adulthood, apparently at a cost to their own body condition. As such, our data indicate the importance of monitoring the body condition of reproductive females as key indicators of nutritional stress that comprise a large component of the population; the data also demonstrate the utility of aerial photogrammetry as a noninvasive method for providing quantitative data on body condition with large sample sizes.

Acknowledgements. This study was conducted with funding support from the NOAA Northwest Regional Office (now West Coast Region), the Southwest Fisheries Science Center and the Northwest Fisheries Science Center. We are particularly grateful to Lynne Barre for her support and encouragement. We thank Dane Armstrong of Friday Harbor Helicopters for his skilled piloting and W. Perryman for technical advice. Staff at the Center for Whale Research assisted with fieldwork. We thank Jane Cogan for providing data summaries for the Albion test fishery. All aerial and boat-based operations around whales were conducted under the authority of National Marine Fisheries Service Permits \#532-1822 and \#155569 in the USA, and Species-At-Risk Act Permit \#13-278 in Canada.

\section{LITERATURE CITED}

Bradford AL, Weller DW, Punt AE, Ivashchenko YV, Burdin AM, VanBlaticom GR, Brownell RL (2012) Leaner leviathans: body condition variation in a critically endangered whale population. J Mammal 93:251-266
Fearnbach H, Durban J, Ellifrit D, Balcomb KC (2011) Size and long-term growth trends of Endangered fish-eating killer whales. Endang Species Res 13:173-180

Fisheries and Oceans Canada (2008) Recovery strategy for the northern and southern resident killer whales (Orcinus orca) in Canada. Species at Risk Act Recovery Strategy Series, Ottawa. www.sararegistry.gc.ca/document/ default_e.cfm?documentID=1341

Ford JKB, Ellis GM (2006) Selective foraging by fish-eating killer whales Orcinus orca in British Columbia. Mar Ecol Prog Ser 316:185-199

Ford JKB, Ellis GM, Balcomb KC III (2000) Killer whales: the natural history and genealogy of Orcinus orca in British Columbia and Washington State, 2nd edn. University of British Columbia Press, Vancouver

Ford JKB, Ellis GM, Olesiuk PF, Balcomb KC III (2010) Linking killer whale survival and prey abundance: food limitation in the oceans' apex predator. Biol Lett 6: 139-142

* Ford MJ, Hempelmann J, Hanson MB, Ayres KL and others (2016) Estimation of a killer whale (Orcinus orca) population's diet using sequencing analysis of DNA from feces. PLOS ONE 11:e0144956

Foster EA, Franks DW, Morrell LJ, Balcomb KC, Parsons KM (2012a) Social network correlates of food availability in an endangered population of killer whales, Orcinus orca. Anim Behav 83:731-736

Foster EA, Franks DW, Mazzi S, Draden SK, Balcomb KC, Ford JKB, Croft DP (2012b) Adaptive prolonged postreproductive life span in killer whales. Science 337:1313

*Hanson MB, Baird RW, Ford JK, Hempelmann-Halos J and others (2010) Species and stock identification of prey consumed by endangered southern resident killer whales in their summer range. Endang Species Res 11: 69-82

*Hauser DD, Logsdon MG, Holmes EE, VanBlaricom GR, Osborne RW (2007) Summer distribution patterns of southern resident killer whales Orcinus orca: core areas and spatial segregation of social groups. Mar Ecol Prog Ser 351:301-310

Hilborn R, Cox SP, Gulland FMD, Hankin DG, Hobbs NT, Schindler DE, Trites AW (2012) The effects of salmon fisheries on southern resident killer whales: final report of the Independent Science Panel. Prepared with the assistance of D. R. Marmorek and A. W. Hall, ESSA Technologies Ltd., Vancouver, BC for National Marine Fisheries Service, Seattle, WA and Fisheries and Oceans Canada, Vancouver, BC

Joblon MJ, Pokra MA, Morse B, Harry CT and others (2014) Body condition scoring system for delphinids based on short-beaked common dolphins (Delphinus delphis). J Mar Anim Ecol 7:5-13

Miller CA, Best PB, Perryman WL, Baumgartner MF, Moore MJ (2012) Body shape changes associated with reproductive status, nutritive condition and growth in right whales Eubalaena glacialis and E. australis. Mar Ecol Prog Ser 459:135-156

National Marine Fisheries Service (2008) Recovery plan for southern resident killer whales (Orcinus orca). National Marine Fisheries Service, Northwest Region, Seattle, WA. www.nmfs.noaa.gov/pr/pdfs/recovery/whale _killer.pdf

Noren DP (2011) Estimated field metabolic rates and prey requirements of resident killer whales. Mar Mamm Sci 27:60-77 
Olesiuk PF, Bigg MA, Ellis GM (1990) Life history and population dynamics of resident killer whales (Orcinus orca) in the coastal waters of British Columbia and Washington State. Rep Int Whal Comm Spec Issue 12:209-244

Olesiuk PF, Ellis GM, Ford JKB (2005) Life history and population dynamics of northern resident killer whales (Orcinus orca) in British Columbia. Res Doc 2005/45. Canadian Science Advisory Secretariat, Fisheries and Oceans Canada, Ottawa. www.dfo-mpo.gc.ca/csas/Csas/ Publications/ResDocs-DocRech/2005/2005_045_e.htm

Parsons KM, Balcomb KC III, Ford JKB, Durban JW (2009) The social dynamics of southern resident killer whales and conservation implications for this endangered population. Anim Behav 77:963-971

Perryman WL, Lynn MS (2002) Evaluation of nutritive condition and reproductive status of migrating gray whales (Eschrichtius robustus) based on analysis of photogrammetric data. J Cetacean Res Manag 4:155-164

Editorial responsibility: Ana Cañadas, Madrid, Spain
Pettis HM, Rolland RM, Hamilton PK, Brault S, Knowlton AR, Kraus SD (2004) Visual health assessment of North Atlantic right whales (Eubalaena glacialis) using photographs. Can J Zool 82:8-19

Trites AW, Donnelly CP (2003) The decline of Stellar sea lions Eumetopias jubatus in Alaska: a review of the nutritional stress hypothesis. Mammal Rev 33:3-28

* Ward EJ, Holmes EE, Balcomb KC (2009) Quantifying the effects of prey abundance on killer whale reproduction. J Appl Ecol 46:632-640

* Ward EJ, Dahlheim ME, Waite JM, Emmons CK, Marshall KN, Chasco BE, Balcomb KC (2016) Long-distance migration of prey synchronizes demographic rates of top predators across broad spatial scales. Ecosphere 7:1-11

Wright BM, Stredulinsky EH, Ellis GM, Ford JKB (2016) Kindirected food sharing promotes lifetime natal philopatry of both sexes in a population of fish-eating killer whales, Orcinus orca. Anim Behav 115:81-95

Submitted: November 22, 2017; Accepted: January 23, 2018

Proofs received from author(s): March 13, 2018 